\title{
Marine bacterioplankton show bursts of rapid growth induced by substrate shifts
}

\author{
Åke Hagström ${ }^{1, *}$, Jarone Pinhassi' ${ }^{2}$, Ulla Li Zweifel ${ }^{1}$ \\ ${ }^{1}$ Marine Sciences, Kalmar University, Box 905, 39129 Kalmar, Sweden \\ ${ }^{2}$ Department of Microbiology, Umeå University, 90187 Umeå, Sweden
}

\begin{abstract}
Diel dynamics of marine bacterioplankton was monitored at sampling sites in the Bothnian Sea (NB1) and the Mediterranean Sea (Villefranche Bay). At both locations, considerable diel variation was found in bacterial production, with highest values recorded during midday and lower values during night and early morning. The abundance of bacteria scored by the number of nucleoidcontaining cells (NUCC) also changed during the day, with minimum numbers during midday. The bacterial turnover rate based on thymidine incorporation and NUCC varied between $0.22-0.31$ and $0.48-2.40 \mathrm{~d}^{-1}$ in the Bothnian Sea and Mediterranean, respectively. There was a significant positive correlation between the community turnover rate and phosphate concentration both in the Bothnian Sea and in the Mediterranean. In the Mediterranean, nutrient addition experiments showed that phosphate was the least available 'commodity' for the bacterial community. Combined addition of phosphate and glucose stimulated bacterial growth more than a single addition of either substrate alone, reaching a bacterial turnover of $2.4 \mathrm{~d}^{-1}$. This value was equal to the maximum turnover rate found in situ during the daily cycle. Our results suggest that bacterioplankton rapidly adjust their growth rate in response to diel changes in nutrient supply.
\end{abstract}

KEY WORDS: Bacterioplankton $\cdot$ Growth $\cdot$ Substrate

\section{INTRODUCTION}

Early work in the field of bacterial physiology demonstrated the ability of bacteria to respond rapidly to changing nutrient conditions (Maaløe \& Kjeldgaard 1966). Within one generation, bacteria can accommodate to a shift in nutrient quality. This transition between growth rates involves changes in macromolecular composition and cell size as well as a starvationspecific response (Maaløe \& Kjeldgaard 1966, Nyström \& Kjelleberg 1989). It is therefore tempting to regard this complex behavior as an adaptive manifestation of the environmental conditions that bacteria experience in their habitat (Vasi et al. 1994).

In the marine environment, production of pelagic bacteria is controlled by the availability of substrates

\footnotetext{
*E-mail: ake.hagstrom@hik.se
}

and predation - variables that can show considerable daily variation (Larsson \& Hagström 1979, Wikner et al. 1990). As a result, diel dynamics in uptake of ${ }^{3} \mathrm{H}$ thymidine and frequency of dividing cells can be recorded (Hagström \& Larsson 1984, Riemann \& Søndergaard 1984, Riemann et al. 1984, Shiah 1999), yet total bacterial numbers do not show dramatic variations during the day. This contradiction could be explained if the bacterial population dynamics is obscured by a substantial number of damaged or dead cells. The question is whether or not there are reasons to believe that the marine environment harbor dead bacterial cells. In a review on bacterial cell death, Nyström (1998) wrote: 'in times of prosperity prokaryotic cells like E. coli appear to lack an aging process and are essentially immortal. However prokaryotes do die if circumstances arrest multiplication. Cells of a non-differentiating bacterial population entering stationary phase due to the depletion of 
an essential nutrient become moribund and the viable cell counts drop stochastically'. Indeed, several studies in the natural environment have shown that a substantial fraction of the total numbers of marine bacterioplankton are damaged or lack the potential for growth (del Giorgio \& Scarborough 1995, Zweifel \& Hagström 1995, Heissenberger et al. 1996, Karner \& Fuhrman 1997, Vosjan \& van Noort 1998). This supports earlier findings that a highly variable fraction of the bacterial community is metabolically active (Hoppe 1976, Kogure et al. 1978, Meyer-Reil 1978, Zimmermann et al. 1978).

While most marine microbiologists by now will agree with the statement that not all bacteria counted by traditional total counts are active (Stoderegger \& Herndl 1998), the uncertainty is far greater when it comes to suggesting a method to distinguish between active and inactive bacteria. Zweifel \& Hagström (1995) showed that only a fraction of the particles detected as bacteria by traditional staining methods contain a DAPI-stainable nucleoid, the remaining fraction being depicted as bacterial ghosts. They therefore concluded that the specific growth rate of bacterioplankton should be higher than the community turnover obtained when relating ${ }^{3} \mathrm{H}$-thymidine uptake to total counts (Zweifel \& Hagström 1995). Similar results were found earlier using microautoradiography to assess the number of active cells (Riemann et al. 1984). However, Riemann et al. were unable to conclude whether low bacterial activity was a sign of a downshifted metabolism or of dead cells. In this context the presence of a nucleoid in bacterial cells should constitute a more decisive stipulation for judging the condition of cells (Schmid \& von Freiesleben 1996). However, it has been shown that a certain fraction of the non-nucleoid containing cells appear to have the ability to resume growth (Choi et al. 1996). These cells may represent resting stages with highly impermeable membranes that fail to take up dye, and during nutrient or temperature shifts in seawater cultures these cells could resume growth. In any case, the presence of nucleoid-containing cells (NUCC) is indicative of active or recently active cells, as concluded by Choi et al. This conclusion is in agreement with the results of Gasol et al. (1999), who used different staining techniques, including NUCC, together with flow cytometry and microscopy to identify the dynamic members of bacterioplankton.

In this paper we report the results of experiments investigating variations in thymidine incorporation, total counts of bacteria and NUCC numbers to determine diel variations in bacterioplankton activity in relation to mineral nutrient concentrations. Our results indicate that marine bacteria in the euphotic layer express bursts of rapid growth induced by diel variations in their growth conditions.

\section{MATERIALS AND METHODS}

Diel studies were performed in September 1994 at a routine sampling station, NB1, in the northern

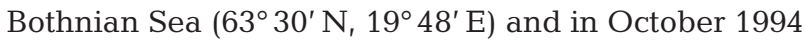
nearshore in the Bay of Villefranche-sur-Mer in the Mediterranean Sea $\left(43^{\circ} 41^{\prime} N, 7^{\circ} 19^{\prime} E\right)$. Salinity and temperature were $6 \%$ and $16^{\circ} \mathrm{C}$ in the Bothnian Sea and $35 \%$ and $21^{\circ} \mathrm{C}$ in the Mediterranean, respectively. At both locations, surface water was collected continuously through a 0.5 inch $(1.25 \mathrm{~cm} \varnothing)$ PVC tubing and submerged pump placed at $2 \mathrm{~m}$ depth. Samples for nutrients, bacterial numbers and bacterial production were drawn from this continuous supply.

Water for the nutrient samples was transferred via a peristaltic pump and thin tube (Tygon $2 \mathrm{~mm}$ i.d.) to a flow-through cuvette sampled by an autoanalyzer (Technicon TRAACS 800). The residence time in the tube was $<5$ min. Reactive phosphate and ammonium were measured every 3 min using the autoanalyzer. A standard was run after every fifth sample.

Traditional total counts of bacteria were determined every second to third hour from single samples with fluorescent staining, using either Acridine Orange or 4', 6-diamidino-2-phenylindole (DAPI) (Hobbie et al. 1977, Porter \& Feig 1980). A final concentration of $2 \mu \mathrm{g}$ DAPI $\mathrm{ml}^{-1}$ sample was used for DAPI-stained samples. Numbers of NUCC were quantified according to Zweifel \& Hagström (1995). The number of fields counted was adjusted to maintain a standard error of the microscopic enumeration below $5 \%$ (typically 20 fields). The number of cells with dividing nucleoids was determined simultaneously - cells with 2 nucleoids within the same cell boundary were scored as dividing. For a closer discussion on the behavior of the bacterial nucleoid see Cooper (1991).

Bacterial production was measured by uptake of ${ }^{3} \mathrm{H}$-thymidine (Fuhrman \& Azam 1980) as modified by Smith \& Azam (1992). Triplicate samples were incubated under in situ conditions. A conversion factor of $1 \times 10^{18}$ cells $\mathrm{mol}^{-1}$ incorporated thymidine was applied to the Bothnian Sea samples (as determined experimentally: Zweifel \& Hagström 1995), and the published factor of $1.7 \times 10^{18} \mathrm{cells} \mathrm{mol}^{-1}$ incorporated thymidine (Fuhrman \& Azam 1980) was applied to the samples from the Mediterranean. The different conversion factors are warranted due to the different conditions in the 2 sea areas (primarily the higher abundance of humic substances in the Baltic). The standard deviation for incorporation of ${ }^{3} \mathrm{H}$-thymidine was $\leq 10 \%$ of the mean of triplicate samples and blanks.

Nutrient-addition experiments were performed in the Mediterranean by adding combinations of carbon, nitrogen and phosphorus to $250 \mathrm{ml}$ whole seawater 
samples contained in acid-rinsed $(1 \mathrm{M} \mathrm{HCl})$ polycarbonate bottles (Nalgene). Nutrients were added to give an addition of $40 \mu \mathrm{M} \mathrm{C}$ (glucose), $2 \mu \mathrm{M} \mathrm{N}\left(\mathrm{NH}_{4} \mathrm{Cl}\right)$ and $0.2 \mu \mathrm{M} \mathrm{P}$ $\left(\mathrm{Na}_{2} \mathrm{HPO}_{4}\right)$. The samples were incubated in situ for $12 \mathrm{~h}$. The initial concentration of inorganic nutrients was $10 \mathrm{nM} \mathrm{PO}_{4}-\mathrm{P}$ and $90 \mathrm{nM} \mathrm{NH}_{4}-\mathrm{N}$.

\section{RESULTS AND DISCUSSION}

During diel experiments in the northern Bothnian Sea, and in the NW Mediterranean Sea the dynamics in bacterial numbers, both as traditional total counts (TC) and as NUCC, were analyzed in relation to bacterial production and inorganic nutrient concentrations. At both locations, NUCC showed diel variations, with maximum numbers in late evening and minimum numbers at midday, although no clear differences could be found in the total counts of bacteria (Fig. 1). NUCC made up 33 to $39 \%$ of TC in the Bothnian Sea and 12 to $29 \%$ in the Mediterranean.

The highest bacterial production was recorded during midday both in the Bothnian Sea and in the Mediterranean, with lower values at night and early morning. A similar diel pattern was found by Gasol et al. (1998) at offshore sampling locations in the NW Mediterranean Sea. In the Mediterranean, the integrated production during the $9 \mathrm{~h}$ of rapid growth (09:00 to 18:00 h) made up $66 \%$ of the daily bacterial production (Fig. 1). In the Bothnian Sea, the daily changes were less dramatic, possibly due to lower temperature and low primary productivity at the time of sampling (Hagström et al. 1983).

The rate of turnover $(\mu)$ of bacteria was calculated as $\mu=\mathrm{BP} / \mathrm{NUCC}$ using the bacterial production (BP) derived from ${ }^{3} \mathrm{H}$-thymidine uptake and the number of nucleoid-containing bacteria (Fig. 2). The calculated $\mu$ showed a daily variation, with highest bacterial turnover at mid-day and lower values at night. This variation depended equally on diel variations in the rate of thymidine incorporation and the number of NUCC. In the Bothnian Sea, the bacterial turnover varied between 0.22 and $0.31 \mathrm{~d}^{-1}$. A larger variation was found in the Mediterranean, where the daily turnover varied between 0.48 and $2.40 \mathrm{~d}^{-1}$. The possibility that bacteria lacking
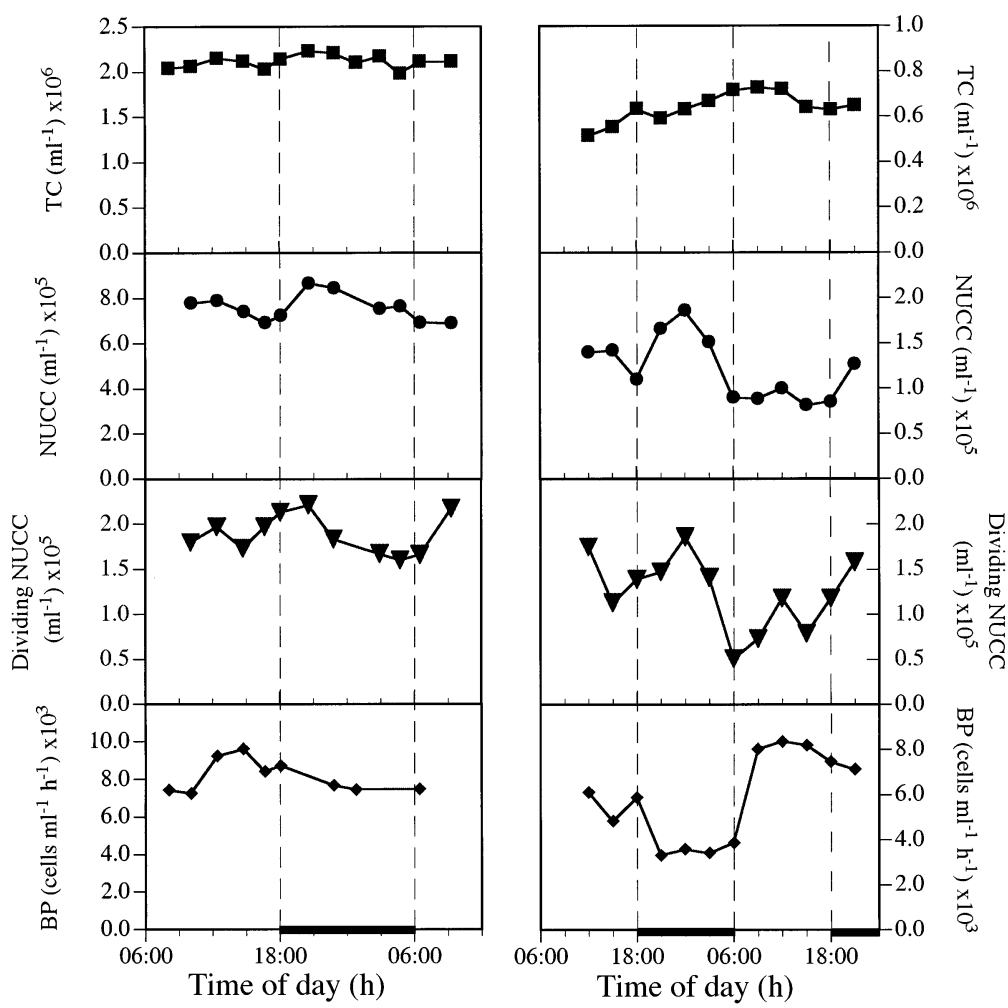

Fig. 1. Diel variation in total counts (TC), nucleoid-containing cells (NUCC), cells with dividing nucleoid (Dividing NUCC), and bacterial production (BP). Left graphs: Site NB1 in the northern Bothnian Sea; right graphs: Bay of Villefranche in the Mediterranean Sea
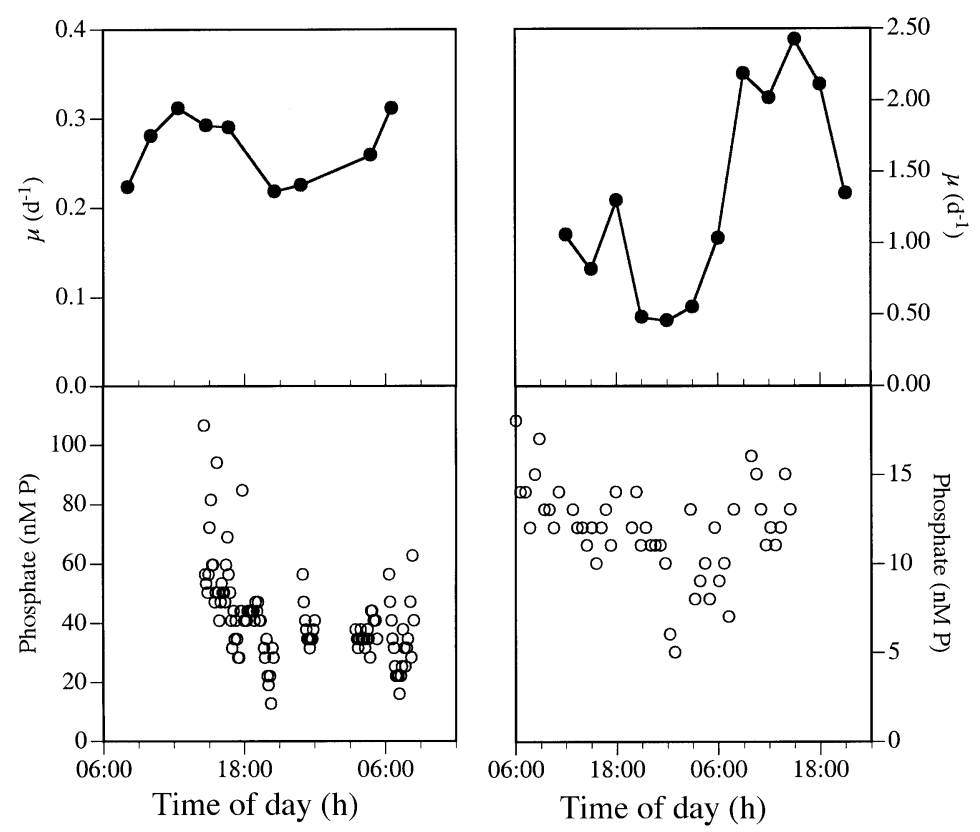

Fig. 2. Diel variation in turnover rates $(\mu)$ of NUCC bacteria and phosphate concentrations. Left graphs: Site NB1 in the northern Bothnian Sea; right graphs: Bay of Villefranche in the Mediterranean Sea 
a stained nucleoid contributed to the thymidine incorporation was not considered in these calculations since this fraction is largely unknown and not easily determined. Also, we recognize that a portion of the bacterial cells containing a stained nucleoid could represent non-growing cells. It has been shown that changes in NUCC status could occur in the absence of an observable increase in cell abundance (Choi et al. 1996, 1999). However, it is not easy to foresee how random variation in these factors could work in concert to produce a diel pattern in $\mu$, as observed in the present study. In the following we therefore interpret the observed diel pattern as a reflection of the growth dynamics of bacteria.
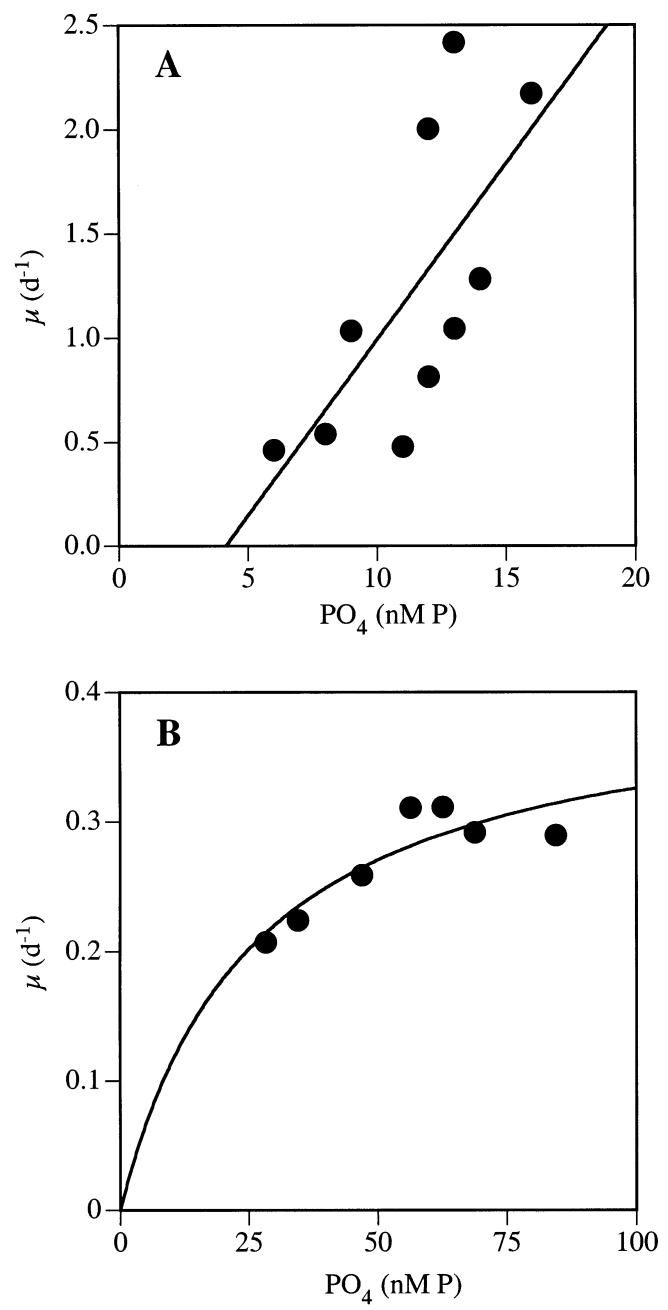

Fig. 3. Turnover rate $(\mu)$ of nucleoid-containing bacteria as a function of phosphate concentration in the Mediterranean (A), and in the Bothnian Sea (B). Data were fitted to a Monodtype saturation equation, where $\mu_{\max }=0.41 \mathrm{~d}^{-1}$ and the halfsaturation constant $K_{\mathrm{S}}=25.7 \mathrm{nM} \mathrm{PO}_{4}$ i this yielded $\mathrm{r}^{2}=0.48$ and $r^{2}=0.78$ for the Mediterranean and the Bothnian Seas, respectively
The pronounced changes in $\mu$ shown in Fig. 2 suggest that bacteria experience marked changes in substrate concentration or quality during the day. Using high-frequency sampling of the ammonium and phosphate concentrations (sampling every $3 \mathrm{~min}$ with a standard calibration every $15 \mathrm{~min}$ ) the influence of mineral nutrients could be investigated (Fig. 2). The high-frequency sampling provided a sufficiently large data set to allow conclusions to be drawn from numbers close to the detection limit of the nutrient analyses. In Fig. 2, each point represents the mean of 5 samples. In the Mediterranean, $\mu$ was positively correlated to phosphate concentration $\left(\mathrm{p}<0.05, \mathrm{r}^{2}=0.48, \mathrm{n}=10\right)$, whereas in the Bothnian Sea no positive linear correlation could be found. Instead, here $\mu$ appeared to reach maximum values at phosphate concentrations above $50 \mathrm{nM}$ (Fig. 3). Thus, Bothnian Sea data were fitted to a Monod-type saturation equation, where $\mu_{\max }=0.41 \mathrm{~d}^{-1}$ and the half-saturation constant $K_{\mathrm{S}}=25.7 \mathrm{nM} \mathrm{PO}_{4}$, which yielded $r^{2}=0.78$. The Mediterranean data fitted to this equation resulted in the same $r^{2}$ value as the linear regression. In the Bothnian Sea, the much greater variation in phosphate concentrations (10 to $100 \mathrm{nM}$ ) made it reasonable to assume that $\mu$ could reach its maximum during periods of high $\mathrm{PO}_{4}$ concentrations. No significant correlation between $\mu$ and ammonium could be found. In our view it is an interesting observation that two such seemingly different systems as the Bothnian Sea and the Mediterranean exhibit daily variations in bacterial numbers, production and phosphate concentrations.

To study the effect of nutrient pulses on the growth of bacteria, a set of nutrient-addition experiments was made in the Mediterranean. Different combinations of carbon, nitrogen and phosphorus were added to whole seawater, and the rate of turnover of NUCC bacteria was calculated after $12 \mathrm{~h}$ incubation. The results showed that phosphate was the 'commodity' least available to the bacterial community (Fig. 4A). As single addition of carbon also increased the turnover, although not to the same extent as phosphate. This effect of $\mathrm{C}$ addition may suggest that an increased energy supply would allow the bacteria to scavenge more inorganic nutrients (Kirchman et al. 1990). The combined addition of carbon and phosphate increased the turnover from 1.4 to $2.4 \mathrm{~d}^{-1}$ (Fig. 4A), which was close to maximum values found during the daily cycle in situ. Releasing growth limitation completely by adding $\mathrm{C}, \mathrm{N}$ and $\mathrm{P}$ together, further increased the turnover 2-fold. In the combined $\mathrm{C}$, $\mathrm{N}$, P treatment, the number of NUCC recorded after $12 \mathrm{~h}$ increased somewhat, while in the other treatments no changes in NUCC numbers were found (Fig. 4B). This experiment demonstrated that the bacterial community was well adapted to take advantage 
of nutrient pulses and that bacteria rapidly exploit enhanced growth conditions.

It has previously been demonstrated that the bacterial communities in both the Bothnian Sea and NW Mediterranean are phosphate limited (Zweifel et al. 1993, 1995, Thingstad et al. 1998), and the data presented here show that the turnover of the bacterial community primarily responded to phosphate availability. In another diel study in the NW Mediterranean, DOC availability was invoked as the driving force for the daily variation in bacterial production (Gasol et al. 1998). However, in a previous study (Zweifel et al. 1993) in the NW Mediterranean, mineral nutrients explained $70 \%$ of the variability in bacterial growth. Adding DOC to the analysis only improved the degree of explanation to $89 \%$ (Zweifel et al. 1993). In this paper, we therefore focused our interest on mineral nutrients. It is however possible that the scenario with bacteria responding to mineral nutrients is indirect. Increased bacterial growth rates mediated by changes in carbon availability could cause a release of phosphate due to enzymatic cleavage of organophosphates (Ammerman \& Azam 1985). If this is the case, fluctuations in the phosphate concentration would represent daily 'overshoots'.

When bacterial assemblages experience shift in growth rates in the marine environment or in culture, uncoupling of DNA and protein synthesis is observed (Chin-Leo \& Kirchman 1990). Thus, cell-cycle dependent processes could be a partial explanation of the diel variation in NUCC numbers. Assuming a doubling of the generation time for every $10^{\circ} \mathrm{C}$ increase in temperature (Herenden et al. 1979), the maximum growth rates in the Mediterranean would be comparable to a generation time of 2.5 to $13 \mathrm{~h}$ at $37^{\circ} \mathrm{C}$. In Escherichia coli growing with a generation time of $80 \mathrm{~min}$, the $\mathrm{D}$ period (the time between completion of DNA replication and cell division) makes up $25 \%$ of the cell cycle, and this fraction increases to $40 \%$ as the generation time becomes more than $10 \mathrm{~h}$ (Chesbro et al. 1990). If diel cycles induced by nutrient availability create pulses/bursts of growth, one might expect a significant lag between the maximum uptake of ${ }^{3} \mathrm{H}$-thymidine (which should coincide with the $\mathrm{C}$ period - the time required for DNA replication) and the actual cell division, and an increase in the number of single cells. A pattern suggesting this sequence of events was evident in the Bothnian Sea, where a peak in thymidine incorporation preceded a peak in the number of cells with a dividing nucleoid followed by an increase in the number of NUCC (Fig. 1). In the Mediterranean, a similar but less clear pattern could be seen. In $E$. coli it has been demonstrated that 'a majority of the exponentially growing cells contained two separated nucleoids' while 'in stationary-phase cells, a majority of the cells contained only one nucleoid' (Åkerlund et al. 1995). In thermophilic Archaea, it has similarly been demonstrated that 'the nucleoids were highly organized during exponential growth, whereas an unstructured appearance was observed in stationary-phase cells' (Poplawski \& Bernander 1997). Thus it would seem
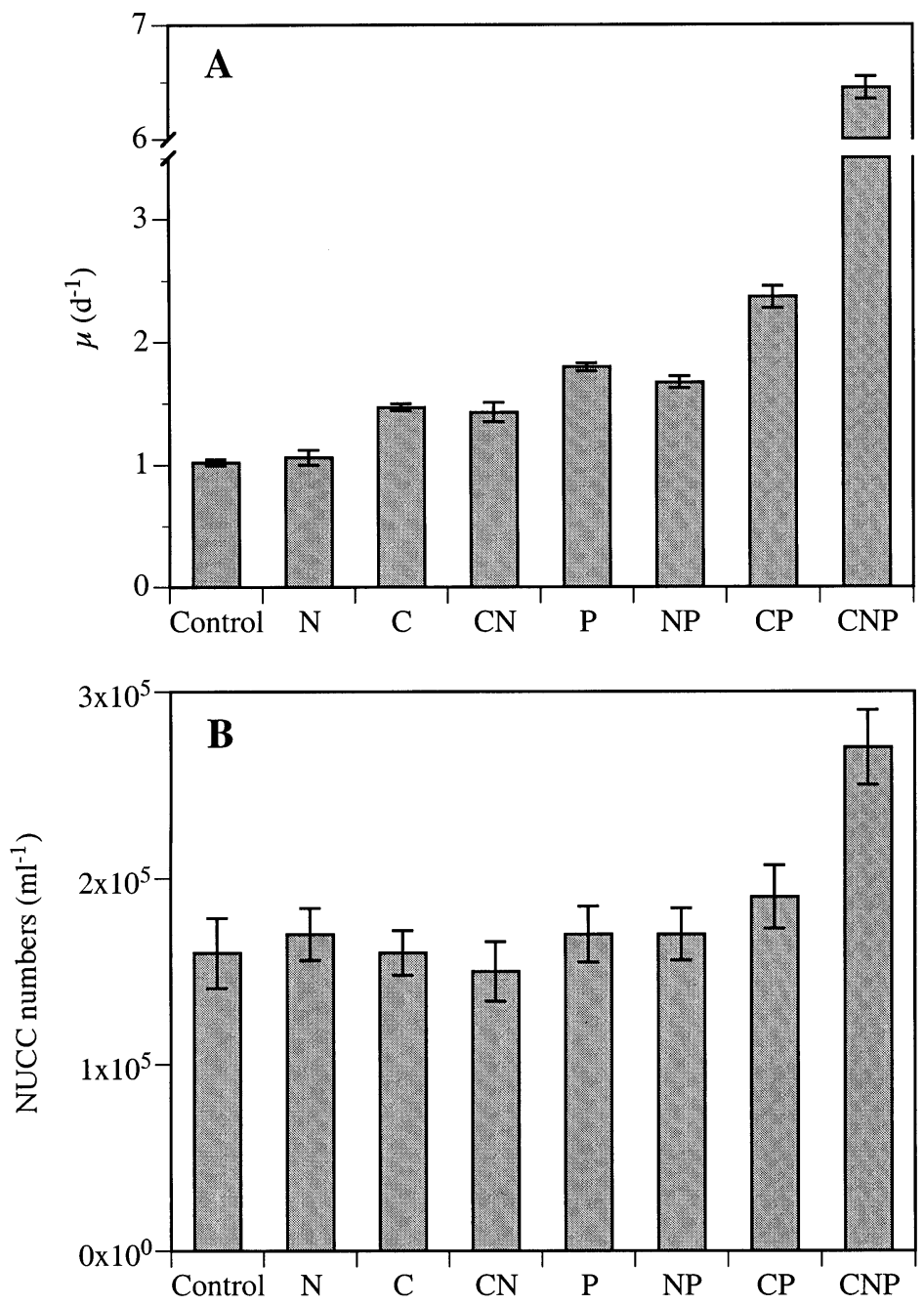

Fig. 4. (A) Changes in turnover rates of NUCC bacteria in the Mediterranean induced by nutrient addition; resulting turnover rate was statistically examined using $2 \times \mathrm{SE}$ as an approximation of the $95 \%$ confidence interval for the mean (Zar 1984). (B) Number of nucleoidcontaining cells after $12 \mathrm{~h}$ incubation in the different treatments. $\mathrm{N}$ : ammonium addition; P: phosphate addition; C: glucose addition; CN: glucose plus phosphate; NP: ammonium plus phosphate; CP: glucose plus phosphate; CNP: glucose plus ammonium and phosphate 
likely that the variation in dividing NUCC numbers indicates a response to changing growth conditions. In order to maintain a steady state in bacterial numbers over longer periods of time, the observed daily bursts of growth must be counterbalanced by mortality. Diel variation in bacterivory has been shown to vary up to 20 -fold, mainly due to variation in the per-cell feeding rate of heterotrophic flagellates (Wikner et al. 1990). Mortality by virus lysis is also a distinct possibility, although to our knowledge a diel pattern in bacterial lysis has not been shown.

The growth rates obtained in the present study are higher than those calculated using traditional total counts because of the lower proportion of NUCC cells. Considering the possibility that not all NUCC cells are actively growing (e.g. because of virus infection), the true growth rates of the active bacterioplankton are likely to be even higher than the numbers presented here. At the same time, slow-growing bacteria might well be dominant components of the bacterioplankton due to their ability to exploit low-quality substrates (Button et al. 1998). We have previously demonstrated 5 -fold higher net specific growth rates of individual bacterial species compared to total community turnover, i.e. thymidine incorporation related to total counts, in seawater mesocosms (Pinhassi et al. 1999). In Pinhassi et al.'s study, a species-specific wholegenome hybridization protocol was used, allowing the growth of individual populations in a mixed natural community to be recorded. Also, studies of the number of CTC-positive cells have suggested that marine bacteria grow faster than indicated by the community turnover (del Giorgio \& Scarborough 1995, Sherr et al. 1999). Furthermore, it has been proposed that CTCpositive cells (typically lower than NUCC numbers in situ) are responsible for the bulk of bacterial metabolism (Sherr et al. 1999).

In conclusion, the short-term variability in the growth environment for bacterioplankton and the estimated fast turnover rates indicate a microbial habitat of the sea that is teeming with life. In addition to the heterogeneous distribution in space depicted by Azam (1998), we would like to add the importance of shortterm dynamics that allow bacteria to take advantage of a changing environment.

Acknowledgements. Åsa Rudehäll and Carl-Henrik Stangenberg are acknowledged for technical assistance and Dr Erik Lundberg for expertise on nutrient analysis. Our work in Villefranche-sur-Mer was much facilitated by the kind support of Dr Fereidoun Rassoulzadegan. This work was supported by grants from the Swedish Natural Science Council (B-AA/BU 04452-320) and from the Commission of the European Communities, MAST II grant MAS 2-CT93-0063 'Medipelagos'.

\section{LITERATURE CITED}

Åkerlund T, Nordström K, Bernander R (1995) Analysis of cell size and DNA content in exponentially growing and stationary-phase batch cultures of Escherichia coli. J Bacteriol 177:6791-6797

Ammerman JW, Azam F (1985) Bacterial 5'-nucleotidase in aquatic ecosystems: a novel mechanism of phosphorus regeneration. Science 227:1338-1340

Azam F (1998) Microbial control of oceanic carbon flux: the plot thickens. Science 280:694-696

Button DK, Robertson BR, Lepp PW, Schmidt TM (1998) A small, dilute-cytoplasm, high-affinity, novel bacterium isolated by extinction culture and having kinetic constants compatible with growth at ambient concentrations of dissolved nutrients in seawater. Appl Environ Microbiol 64: $4467-4476$

Chesbro W, Arbige M, Eifert R (1990) When nutrient limitation places bacteria in the domains of slow growth: metabolic, morphologic and cell cycle behavior. FEMS Microbiol Ecol 74:103-120

Chin-Leo G, Kirchman DL (1990) Unbalanced growth in natural assemblages of marine bacterioplankton. Mar Ecol Prog Ser 63:1-8

Choi JW, Sherr EB, Sherr BF (1996) Relation between presence-absence of a visible nucleoid and metabolic activity in bacterioplankton cells. Limnol Oceanogr 41:1161-1168

Choi JW, Sherr BF, Sherr EB (1999) Dead or alive? A large fraction of ETS-inactive marine bacterioplankton cells, as assessed by the reduction of CTC, can become ETS-active with incubation and substrate addition. Aquat Microb Ecol 18:105-115

Cooper S (1991) Bacterial growth and division. Academic Press, San Diego

del Giorgio PA, Scarborough G (1995) Increase in the proportion of metabolically active bacteria along gradients of enrichment in freshwater and marine plankton: implications on estimates of bacterial growth and production rates. J Plankton Res 17:1905-1924

Fuhrman J, Azam F (1980) Bacterioplankton secondary production estimates for coastal waters of British Columbia, Antarctica, and California. Appl Environ Microbiol 39: 1085-1095

Gasol JM, Doval MD, Pinhassi J, Calderón-Paz JI, GuixaBoixareu N, Vaqué D, Pedrós-Alió C (1998) Diel variations in bacterial heterotrophic activity in the northwestern Mediterranean Sea. Mar Ecol Prog Ser 164:107-124

Gasol JM, Zweifel UL, Peters F, Fuhrman JA, Hagström ^̊ (1999) Significance of size and nucleic acid content heterogeneity as measured by flow cytometry in natural planktonic bacteria. Appl Environ Microbiol 65: 4475-4483

Hagström ^̊, Larsson U (1984) Diel and seasonal variation in growth rates of pelagic bacteria. In: Hobbie JE, Williams PJL (eds) Heterotrophic activity in the sea. Plenum Publishing Corp, New York, p 249-262

Hagström $\AA$, Andersson A, Öquist G (1983) Algal and bacterial production in a coastal area (Norrbyn) of the northern Bothnian Sea. Aquilo Ser Zool 22:131-137

Heissenberger A, Leppard GG, Herndl GJ (1996) Relationship between the intracellular integrity and the morphology of the capsular envelope in attached and free-living marine bacteria. Appl Environ Microbiol 62:4521-4528

Herenden SL, van Gogelen RA, Neidhardt FC (1979) Levels of major proteins of Escherichia coli during growth at different temperatures. J Bacteriol 139:185

Hobbie JE, Daley RJ, Jasper S (1977) Use of Nuclepore filters 
for counting bacteria by fluorescence microscopy. Appl Environ Microbiol 33:1225-1228

Hoppe HG (1976) Determination and properties of actively metabolizing heterotrophic bacteria in the sea, investigated by means of micro-autoradiography. Mar Biol 36: 291-302

Karner M, Fuhrman JA (1997) Determination of active marine bacterioplankton: a comparison of universal 16Sr RNA probes, autoradiography, and nucleoid staining. Appl Environ Microbiol 63:1208-1213

Kirchman DL, Keil RG, Wheeler PA (1990) Carbon limitation of ammonium uptake by heterotrophic bacteria in the subarctic Pacific. Limnol Oceanogr 35:1258-1266

Kogure K, Simidu U, Taga N (1978) A tentative direct microscopic method for counting living marine bacteria. Can J Microbiol 25:415-420

Larsson U, Hagström $\AA$ (1979) Phytoplankton exudate release as an energy source for the growth of pelagic bacteria. Mar Biol 52:199-206

Maaløe O, Kjeldgaard NO (1966) Control of macromolecular synthesis. WA Benjamin, Inc, New York

Meyer-Reil LA (1978) Autoradiography and epifluorescence microscopy combined for the determination of number and spectrum of actively metabolizing bacteria in natural waters. Appl Environ Microbiol 36:506-512

Nyström T (1998) To be or not to be: the ultimate decision of the growth-arrested bacterial cell. FEMS Microbiol Rev 21:283-290

Nyström T, Kjelleberg S (1989) Role of protein synthesis in the cell division and starvation induced resistance to autolysis of a marine Vibrio during the initial phase of starvation. J Gen Microbiol 135:1599-1606

Pinhassi J, Azam F, Hemphälä J, Long RA, Martinez J, Zweifel UL, Hagström $\AA$ (1999) Coupling between bacterioplankton species composition, population dynamics, and organic matter degradation. Aquat Microb Ecol 17: $13-26$

Poplawski A, Bernander R (1997) Nucleoid structure and distribution in thermophilic Archaea. J Bacteriol 179: 7625-7630

Porter KG, Feig YS (1980) The use of DAPI for identifying and counting aquatic microflora. Limnol Oceanogr 25:943-948

Riemann B, Søndergaard M (1984) Measurements of diel rates of bacterial secondary production in aquatic environments. Appl Environ Microbiol 47:632-638

Riemann B, Nielsen P, Jeppesen M, Marcussen B, Fuhrman JA (1984) Diel changes in bacterial biomass and growth rates in coastal environments, determined by means of thymidine incorporation into DNA, frequency of dividing

Editorial responsibility: James Hollibaugh,

Athens, Georgia, USA cells (FDC), and microautoradiography. Mar Ecol Prog Ser $17: 227-235$

Schmid MB, von Freiesleben U (1996) Nucleoid segregation. In: Neidhardt FC (eds) Escherichia coli and Salmonella: cellular and molecular biology. American Society for Microbiology, Washington, DC, p 1662-1671

Sherr BF, del Giorgio P, Sherr EB (1999) Estimating abundance and single-cell characteristics of respiring bacteria via the redox dye CTC. Aquat Microb Ecol 18:117-131

Shiah FK (1999) Diel cycles of heterotrophic bacterioplankton abundance and production in the ocean surface waters. Aquat Microb Ecol 17:239-246

Smith DC, Azam F (1992) A simple, economical method for measuring bacterial protein synthesis in sea water using 3H-leucine. Mar Microb Food Webs 6:107-114

Stoderegger K, Herndl GJ (1998) Production and release of bacterial capsular material and its subsequent utilization by marine bacterioplankton. Limnol Oceanogr 43:877-884

Thingstad TF, Zweifel UL, Rassoulzadegan F (1998) Indications of P-starvation/limitation for both phytoplankton and heterotrophic bacteria in the NW Mediterranean summer surface waters. Limnol Oceanogr 43:88-94

Vasi F, Travisano M, Lenski RE (1994) Long-term experimental evolution in Escherichia coli. II. Changes in life history traits during adaptation to a seasonal environment. Am Nat 144:432-456

Vosjan JH, van Noort GJ (1998) Enumerating nucleoid-visible marine bacterioplankton: bacterial abundance determined after storage of formalin fixed samples agrees with isopropanol rinsing method. Aquat Microb Ecol 14: 149-154

Wikner J, Rassoulzadegan F, Hagström Å (1990) Periodic bacterivore activity balances bacterial growth in the marine environment. Limnol Oceangr 35:313-324

Zar JH (1984) Biostatistical analysis. Prentice-Hall, Englewood Cliffs, NJ

Zimmermann R, Iturriaga R, Becker-Birck J (1978) Simultaneous determination of the total number of aquatic bacteria and the number thereof involved in respiration. Appl Environ Microbiol 36:926-935

Zweifel UL, Hagström $\AA$ (1995) Total counts of marine bacteria include a large fraction of non-nucleoid-containing bacteria (ghosts). Appl Environ Microbiol 61:2180-2185

Zweifel U, Norrman B, Hagström $\AA$ (1993) Consumption of dissolved organic carbon by marine bacteria and demand for inorganic nutrients. Mar Ecol Prog Ser 101:23-32

Zweifel UL, Wikner J, Hagström Å, Lundberg E, Norrman B (1995) Dynamics of dissolved organic carbon in a coastal ecosystem. Limnol Oceanogr 40:299-305

Submitted: August 1, 2000; Accepted: January 2, 2001

Proofs received from author(s): April 6, 2001 